\title{
DETERMINANTS OF THE ADOPTION OF FARM MANAGEMENT PRACTICES FOR SUSTAINABLE CROP PRODUCTION AMONG FARMERS IN SOUTHERN PART OF KADUNA STATE, NIGERIA
}

\author{
Bonet Rikichi ATIYONG * \\ Kaduna State University, Department of Geography, Kaduna, Nigeria, \\ e-mail: atiyongbonet@yahoo.com \\ Emmanuel Okunlola ORIOLA \\ University of Ilorin, Department of Geography and Environmental Management, Ilorin, Nigeria, \\ e-mail: lolaoriola@gmail.com \\ Ananias Nkom SANKEY \\ Kaduna State University, Department of Geography, Kaduna, Nigeria, \\ e-mail: ananiassankey@gmail.com
}

Citation: Atiyong, B.R., Oriola, E.O., \& Sankey, A.N. (2020). Determinants of the Adoption of Farm Management Practices for Sustainable Crop Production Among Farmers in Southern Part of Kaduna State, Nigeria. Analele Universităţii din Oradea, Seria Geografie, 30(1), $97-$ 106. https://doi.org/10.30892/auog.301111-836

\begin{abstract}
This study examines the determinants of farmers' adoption of farm management practices (FMPs) that enhances sustainable crop production and ultimately facilitates food security in Southern Kaduna, Nigeria. A total of 1137 registered members of Fertilizer Farmers Association (FFA) during the 2016/2017 farming season were identified in which 286 farmers were purposively sampled for the study. Data were elicited through questionnaire administration. Descriptive statistics and logit regression were adopted in the analyses of the data. The results of the study showed that crop rotations, mixed cropping, use of inorganic/organic fertilizer, traditional tillage system, and minimum tillage/mulching were the common FMPs used by farmers. However, intermittent fallow system and surface irrigation practice were not popular because of poor infrastructural facilities. Similarly, the most common FMPs adopted in Katugal was minimum tillage/mulching, surface irrigation system in Madakiya, mixed cropping was very common in Mailafiya and Zankam, while intermittent short fallow in Kurmin Sara. Age, family size, land tenure, farm size and distance of plot from homestead had influenced significantly on the choice of FMPs. Also, the major determinants of farmers' adoption for FMPs were farming experience $(75.9 \%)$ and soil fertility status of the farmlands $(68.9 \%)$. The study therefore, recommends the revitalization of abandoned irrigation infrastructures in Kagoro and Madakiya, and improves the popularity of traditional tillage and soil mulching among the Southern Kaduna farmers to achieve sustainable crop production and food security.
\end{abstract}

Key words: land, management practices, food security, sustainability, agro-ecological zone

$$
* \quad * \quad * * * *
$$




\section{INTRODUCTION}

Pressure on land resources and demand for food throughout the world has resulted for increase of agricultural land use and intensive agricultural purposes. In Nigeria, there is fast growing human population as well demanding the natural resources couple with agricultural activities. Geissen et al. (2009) observed that intensive land use may cause an important change in soil characteristics that can affect fertility, increase erosion and compaction as well as food security. Similarly under this circumstance, significant soil deterioration and depletion of soil nutrient fertility can lead to reduction in land productivity. However, Ersado et al. (2004) observed that adoption of technical efficiency and productive farming practices can enhance agricultural productivity and improve environmental sustainability that remains the most practical agricultural option for achieving economic growth, food security, and poverty alleviation in Sub-Saharan African Countries. Thus, Terr Africa Partnership (TAP, 2006) explain clearly that farm management practices is the adoption of land use systems that enable land users to maximize the economic and social benefits of the land, while at the same time maintaining or enhancing the ecological functions of the land resources for support of the continued use of the land resources.

Land sustainability is very vital to farmers' means of sustenance that any constraint to land use is affecting subsistence farmers in many ways as observed by Adekoya (1997) cited in Raufu and Adetunji (2012) that subsistent farmers are faced with a lot of constraints for integrating different farm management practices as well, this has affected the sustainability of crop yields. Kong (2014) and Global Environmental Facility (GEF, 2016) however, attributed these constraint to many factors which include insufficient capital, poverty, lack of knowledge or confidence to make a change, lack of financial incentives, land tenure dichotomy, labour constraint and poor infrastructures, low educational level of farmers, limited knowledge of inputs, poor fertility status of soil and unsustainability of some practices. The understanding of these constraints farmers' can use sustainable management practices that would boost farmers' morale to involve in applying different farm management practices in areas of inadequacy that need improvement in order to sustain crop productions.

Furthermore, in a bid to sustain crop production and improve soil fertility status in Nigeria, farming communities adopts different farm management practices such as conventional and conservation tillage system, organic fertilization, inorganic fertilizer application, irrigation agriculture, mono-cropping, mixed cropping and crop rotation among others. Some of these farm management practices may produce high yield while some may instead lead to degradation and depletion of soil nutrient fertility of the agricultural lands. Lal (2015) stressed that adoption of appropriate site-specific techniques, restoring soil quality, conservation agriculture, integrated nutrient management, and continuous vegetative cover such as residue mulch, cover cropping and controlled grazing at appropriate stocking rates among others improve high crop yields and sustains the soil fertility status.

Thus, to achieve sustainable crop production and future food security in Southern Kaduna in particular, a good knowledge of farmers' participation and adoption of different farm management practices is necessary. Therefore, this study examines determinants of farmers adoption of farm management practices in Southern Kaduna located in the vicinity of Nigerian Guinea Savannah Agro-ecological Zone with a view to establish the factors influencing the farmers choice of different farm management practices that facilitate sustainable crop production in the study area.

\section{THE STUDY AREA}

Southern Kaduna lies within the Guinea Savanna Agro-ecological Zone of Nigeria, covering approximately $24,536 \mathrm{~km}^{2}$ and lies between latitudes $9^{\circ} 00^{\prime} 00^{\prime}$ ' and $10^{\circ} 45^{\prime} 00^{\prime}$ 'North of the Equator and longitudes $7^{\circ} 10^{\prime} 00^{\prime \prime}$ 'and $8^{\circ} 45^{\prime} 00^{\prime \prime}$ East of the Greenwich Meridian. The study area shares boundaries with Niger State in the West, Federal Capital Territory (FCT) and Plateau State to the South and South-East, Bauchi States in the East and Kano in the North (figure 1). 
The climate of the study area is classified as Koppen's Aw with two distinct seasons, a wet season and a dry season. Rainfall occurs between the months of April and October with a peak in August, while the dry season extends from the end of October of one calendar year to April of the next. The mean annual rainfall is about $1733 \mathrm{~mm}$ in Kafanchan-Kagoro areas in the Southern part of the study area (Abaje et al., 2010) this is due to the influence of the Jos Plateau with orographic effect. The rainfall in the central part of Kaduna reached about $1203 \mathrm{~mm}$. The mean monthly temperature is $28^{\circ} \mathrm{C}$, while the mean relative humidity is about $63 \%$ (Abaje et al., 2016).

The vegetation of the study area is the Guinea Savanna type influencing the formation organic matter of the main type of soil known as Ferruginous tropical soil. According to Abaje et al. (2010) the soil is affected by the climate, vegetation, lithology and the topography of the area. The soils are well drained and shallow, with texture consisting of loamy sand to sandy loam top soils $(0-20 \mathrm{~cm})$ and supports wide variety of annual, perennial and tree crops respectively (Aregheore, 2005). The relief according to Abaje et al. (2009) is relatively flat and undulating influences the formation of the drainage pattern of the study area.

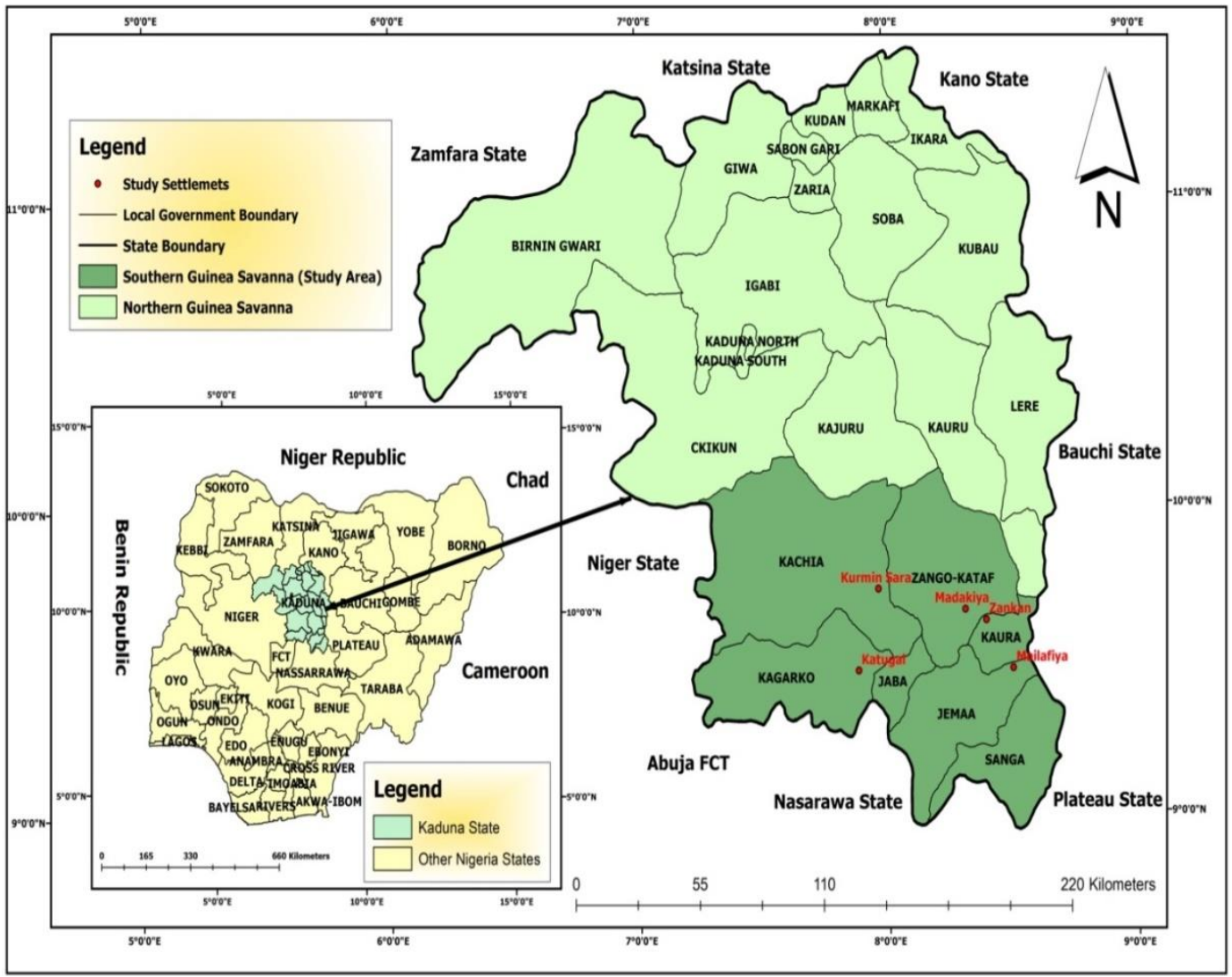

Figure 1. Location of the study Area

(Source: Ministry of Land Survey Kaduna State, 2017)

\section{MATERIALS AND METHODS}

\section{Data Required and Sampling Techniques}

The data required for this paper include: demographic characteristics of the farmers, land tenure (ownership of farm plot), types of crop grown, distance of farm plot from farmers' houses, factors influencing farmers' choice of farm management practice. 
Purposive sampling technique was used to select five local government areas (LGAs) (Kaura, Kagarko, Kachia, Zango Kata and Jema'a) from the seven LGAs of Southern Kaduna. The same sampling technique was used to pick five villages from each LGAs identified located in Guinea Savanna Agro-ecological Zone. Using Cohen et al. (2011) table of sample size determination, at 95\% confidence level, 286 sample size was decided and picked from 1137 registered members cultivated lands in 2016/2017 cropping season. The total number of respondents was selected in each settlement as follows: Zankam (55), Katugal (60), Madakiya (35), Mailafiya (70) and Kurmin Sara (61).

Copies of structured questionnaire were administered to 286 registered farmers' selected using table of random numbers in the five sampled villages, then 281 copies of the questionnaire were completed correctly and found useful for the research analysis.

\section{Analytical Technique}

The data collected were subjected to descriptive method and inferential statistical technique that included percentage and logit regression analysis and presented in bar graph.

\section{RESULTS AND DISCUSSION}

Farmers' Adoption of the Common FMPs for the Sustainability of Crop Production The result of multiple responses on the different farm management practices commonly used by farmers in Southern Kaduna is presented in table 1.

Table 1. Multiple Response on all Adoptable Farm Management Practices Source: Field Survey, 2017

\begin{tabular}{|c|l|c|c|}
\hline \multirow{2}{*}{ S/No. } & \multirow{2}{*}{ Farm management practices } & Responses & \multicolumn{2}{|c|}{ Percentage } \\
\cline { 2 - 4 } & & 20 & 1.3 \\
\hline 1 & Intermittent long fallow & 64 & 4.1 \\
\hline 2 & Intermittent short fallow & 156 & 10.1 \\
\hline 3 & Minimum tillage/mulching & 40 & 2.6 \\
\hline 4 & Zero tillage & 210 & 13.5 \\
\hline 5 & Conventional tillage & 9 & .6 \\
\hline 6 & Contour bund & 79 & 5.1 \\
\hline 7 & Construction of ridges across the slope & 169 & 10.9 \\
\hline 8 & Organic farming (animal manure) & 227 & 14.6 \\
\hline 9 & Use of inorganic fertilizer & 61 & 3.9 \\
\hline 10 & Organic Compost & 235 & 15.1 \\
\hline 11 & Mixed cropping & 252 & 16.2 \\
\hline 12 & Crop Rotation & 30 & 1.9 \\
\hline 13 & Surface irrigation & 1552 & 100.0 \\
\hline 14 & Total & & \\
\hline
\end{tabular}

$\mathrm{mr}=$ Multiple Responses

The use of farm management practices varied in proportion with $13.5 \%$ farmers engaged in the conventional tillage and $12.7 \%$ engaged in minimum tillage/mulching and zero tillage. The result also revealed that $14.6 \%$ of the respondents used inorganic fertilizer only as soil conditioner while $10.9 \%$ of them engaged in the used of organic farming (use of animal dung) and in most cases farmers mixed with inorganic fertilizer for those farmers who could afford the two soil conditioners. Crop rotation $(16.2 \%)$ and mixed cropping $(15.1 \%)$ were also the predominant farming practices. The used of organic compost (3.9\%) was not common in the rural communities. Due to the high growth in population and the subsequent pressure on agricultural lands, only $5.4 \%$ 
of farmers practiced intermittent short fallow in rural communities with more than enough farmlands to cultivate. Irrigation agriculture was not too commonly practice, about $1.9 \%$ of the respondents only engaged in surface irrigation using the available water channels, water locked and marshy areas. The result is agreed with Oriola (2009) assertion that shows the unreliable supply and distribution of irrigation water leaves many farmers dissatisfied and unwilling to participate in irrigation practice. This also conform to Junge et al. (2008) observation that has widespread acknowledgement with low usage of irrigation because some of the farming system practices declined and degraded soil and water quality (table 1).

Furthermore, the five bolded farm management practices shown in Table 1 indicated the focus areas of this research and cumulatively formed $42.1 \%$ of the adoptive farm management practices. The study has also revealed that, crop rotation, conventional tillage, the use of inorganic fertilizer were also the common management practices adopted in the study area and constituted $44.3 \%$ cumulatively, this was greater than $42.1 \%$ of the focus area used for this study and subsequently the analyses were based on these selected land management practices vis-à-vis the other variables of interest.

\section{Adoption Rate of Farm Management Practices among the Study Settlements}

Figure 2 shows the farm management practices adoption among the five sampled settlements. The result revealed that mixed cropping $(22.6 \%)$ was the most common farm management practices adopted in Zankam settlement. Then followed by surface irrigation practice cited by $13.3 \%$ of the respondents. The least practice was intermittent short fallow and minimum tillage/mulching. In Katugal, minimum tillage/mulching (30.8\%) was the most farm management practice adopted and the least was mixed cropping (17.9\%). In Madakiya farm settlement, surface irrigation was the major practice $(46.7 \%)$ and intermittent short fallow practice $(9.4 \%)$ is the least form of management practice. In Mailafiya, farmers practice mixed cropping (27.2\%) more and the least practice was minimum tillage/mulching (19.2\%). The result also reveals that farmers in Kurmin Sara settlement adopted intermittent short fallow (42.2\%) followed by minimum tillage/mulching $(34.26 \%)$, whereas, none of the farmers in this settlement adopted surface irrigation system as a form of farm management practice.

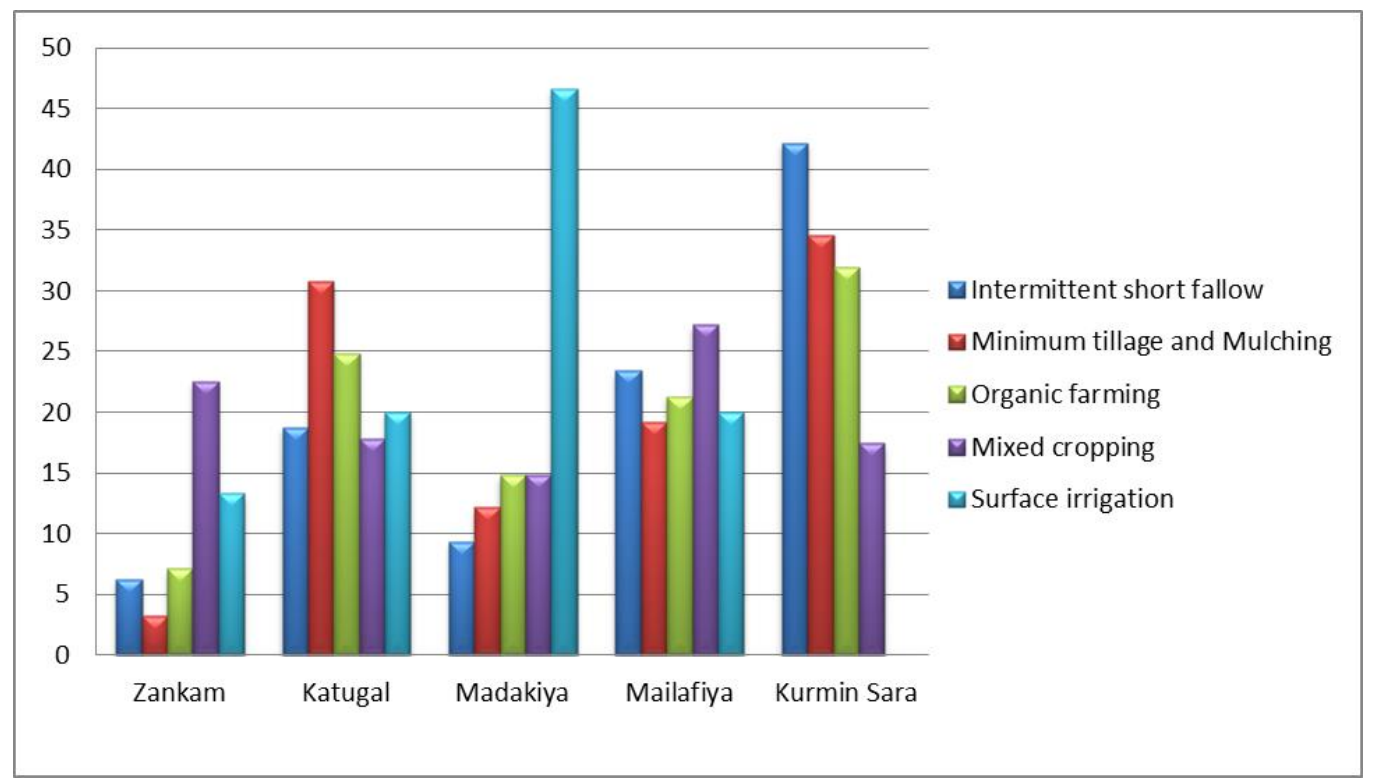

Figure 2. Farm Practices Adoption among the Study Settlements (Source: Field Analysis 2017) 
Generally, the results reveal that, there was no uniform adoption of the farm management practices in all the five sampled settlements. However, while minimum tillage/mulching (32\%) was being the largest adopted farm management practices in Katugal sampled settlement, surface irrigation system in Madakiya (35.35\%), mixed cropping in Mailafiya (42.38\%) and Zankam (67.95), then intermittent short fallow (30.68\%) in Kurmin Sara were the most popularly adopted farm management practices. Babalola and Olayemi (2013) reported similar study that revealed high adoption of mixed cropping and minimum tillage/mulching in Ogun State, Nigeria. The high adoption rate of these practices were attributed to simplicity, moderate cost and effective stabilization of soil fertility.

\section{Demographic / Socio-Economic Attributes and Farm Structural Factors Influencing the Adoption of Farm Management Practices in the Sampled Settlements}

Logit regression model was used to examine the influence of attributes for demographic / socio-economic characteristics for the adoption of farm management practices. Table 2 revealed the result of the model for adoption of farm management practices that influenced by several demographic variables. Age of farmer has influenced positively and significantly to the adoption of intermittent short fallow, surface irrigation and mixed cropping practice at $\mathrm{P}<0.05$. This implies that both young and old farmers have higher probability for adopting the farm management practices in the region, this is probably due to the benefits accrued from these management practices. Muhammad et al. (2014) observed that there were both positive and negative correlation between age of farmers and adoption of conservation farming practices. Families are veritable sources of labour for farm operations and adopted for farm management practices that are labour intensive and are often of great advantage to farm productivity. Household size was positive significantly influenced the adoption of minimum tillage/mulching, organic fertilizer and mixed cropping but influenced negative for intermittent short fallow and surface irrigation. This indicates that households that utilize family labour tend to adopt labour intensive farm management practices. This was concurrent with the findings of Kassie et al. (2009) cited in Miheretu and Yimer (2017) reported that the probability of adopting conservation tillage in Ethiopia was increased with the number of household members. In contrast, Holden and Yohannes (2002) revealed zero relationship between family size and some farm management practices.

Farmers' educational attainment of farmers influenced positively and significantly with mixed cropping practice and not significantly related to the adoption of intermittent short fallow, minimum tillage/mulching and organic fertilizer probably these practices do not need higher educational and technological know-how in the farm management practices. This was conformity with the study of Muhammad et al. (2014) that revealed there was both positive and negative correlation between educational attainment and adoption of farm conservation practices.

According to Bewket (2007) land tenure security is an important factor affecting farmers farming decisions and ownership of land is a major guaranty to changing cropping patterns and management practices. The result indicated that ownership of lands has both positive and negative influence for the adoption of intermittent short fallow, organic fertilizer, mixed farming practice and minimum tillage/mulching. This implies that land owner can secure with courage the provisions of financial incentives required for farming investments in farm management practices affecting significantly farmers decision for choosing a farm management practice. The study of Akpoko's (2004) informed that land tenure influenced significantly positive adoption of farming conservation practices. In the same vain, types of crop grown have positive and significant influence for mixed cropping, intermittent short fallow and organic farming at $\mathrm{P}<0.05$. Similarly, distance from homestead influenced significantly both positive and negative for the adoption of minimum tillage/mulching, organic farming and surface irrigation practice. This implies that any unit increase in distance from homestead resulted for 19\%, $96 \%$ and $26 \%$ probability of adopting minimum tillage/mulching, organic fertilizer and surface irrigation respectively. The implication 
of these results enhanced through targeting of both younger and older families where both spouses work on the farm for full-time basis. Specific farm management practices show positive relationship and significantly influenced by variables such as age, family size, land tenure, farms distance from homestead and farm size but has no significant relationship with educational attainment and types of crop grown as shown by $5 \%$ of farmers. It is imperative to recognize that that education to a certain extent in this study area does not influence adoptive behavior of choice of farm management practices because farmers with many farming experience and knowledge obtained through extension services have made them actually aware of the type of farming that provide high crop yields with necessary and right able inputs appropriate under each soil good condition for conservation measure at the same time.

Table 2. Factors Influencing Farmers' Choice of Farm Management Practices Source: Computed from Field Survey Data, 2017

\begin{tabular}{|c|c|c|c|c|c|c|}
\hline Model & Variables & $\begin{array}{c}\text { Intermittent } \\
\text { short fallow }\end{array}$ & $\begin{array}{c}\text { Minimum } \\
\text { tillage and } \\
\text { mulching }\end{array}$ & $\begin{array}{c}\text { Organic } \\
\text { farming }\end{array}$ & $\begin{array}{c}\text { Mixed } \\
\text { cropping }\end{array}$ \\
\hline $\mathrm{X}_{1}$ & Age of farmer (years) & $0.04(0.02)^{* *}$ & $-0.04(0.01)^{* *}$ & $0.01(0.01)$ & $0.03(0.02)^{* *}$ & $0.02(3.41)^{* *}$ \\
\hline $\mathrm{X}_{2}$ & Household size & $-0.20(0.06)^{* *}$ & $0.06(0.03)^{* *}$ & $0.07(0.03)^{* *}$ & $0.13(0.08)^{* *}$ & $-0.11(0.05)^{* *}$ \\
\hline $\mathrm{X}_{3}$ & Education of the farmer & $-0.37(1.30) \mathrm{ns}$ & $1.40(1.25) \mathrm{ns}$ & $1.73(1.24)$ & $2.31(1.67)^{* *}$ & $-0.42(1.34)$ \\
\hline $\mathrm{X}_{4}$ & ownership of plot & $-1.59(0.34)^{* *}$ & $-0.47(0.27)^{* *}$ & $-1.46(0.30)^{* *}$ & $2.49(0.48)^{* *}$ & $-0.13(0.46)$ \\
\hline $\mathrm{X}_{5}$ & Type of crops grown on & $-0.62(0.55) \mathrm{ns}$ & $-0.32(0.54) \mathrm{ns}$ & $-1.22(0.68)$ & $1.55(0.63)^{* *}$ & $0.50(1.09)$ \\
\hline $\mathrm{X}_{6}$ & $\begin{array}{c}\text { Distance of plot from } \\
\text { homestead }\end{array}$ & $-0.15(0.12) \mathrm{ns}$ & $0.19(0.10)^{* *}$ & $0.15(0.10)$ & $0.96(0.18)^{* *}$ & $-0.26(0.17)^{* *}$ \\
\hline $\mathrm{X}_{7}$ & plot location & $1.35(0.65)^{* *}$ & $0.45(0.65) \mathrm{ns}$ & $1.95(0.88)^{* *}$ & $-0.39(0.86)$ & $-0.45(1.10)$ \\
\hline & Constant & $0.20(1.55)$ & $0.48(1.53)$ & $-0.91(1.59)$ & $-70.52(20.10)$ & $-5.26(2.23)$ \\
\hline & Log Likelihood & $\mathbf{- 1 2 6 . 0 9 8 3 4}$ & $\mathbf{- 1 8 3 . 9 0 6 7 5}$ & $\mathbf{- 1 6 9 . 9 2 3 2}$ & $\mathbf{- 8 2 . 9 2 0 3 7 7}$ & $\mathbf{- 8 6 . 8 3 4 1 1 7}$ \\
\hline & chi2(10) & $\mathbf{5 0 . 8 9}$ & $\mathbf{2 3 . 8 6}$ & $\mathbf{4 4 . 2 9}$ & $\mathbf{1 0 1 . 5 5}$ & $\mathbf{1 7 . 9 1}$ \\
\hline & Prob>chi2 & $\mathbf{0 . 0 0 0 0}$ & $\mathbf{0 . 0 0 1 2}$ & $\mathbf{0 . 0 0 0 0}$ & $\mathbf{0 . 0 0 0 0}$ & $\mathbf{0 . 0 1 2 4}$ \\
\hline
\end{tabular}

Key: $* *$ significant at $0.05 \%, \mathrm{~ns}=$ not significant

\section{Determinants of Farmers' Adoption of Farm Management Practices in Southern Kaduna}

Table 3 shows that majority of the respondents about $29.3 \%$ opined farming experience an determinant factor for adoption of farm management practice, $26.6 \%$ of them cited nature of the farmlands, $15.8 \%$ recognize ownership of many farmlands afford alternative farm management practices and $15.2 \%$ mention large farm size enable the farmer to divide the land into different management practices per season. These four different farm management practices were the major determinants for the adoption of the common farm management practices in the study area. Farmers disagreed that topography as reveal by $4.5 \%$ of them, some $8.6 \%$ also recognize that land and knowledge obtained from participating in government agricultural programme may have not been determinant for adoption of farm management practice. Absence of any government agricultural programme and rugged terrain has hampered agricultural practices in some places of the study area.

Table 3. Determinants of Farmers' Adoption of Farm Management Practices Source: Field Survey, 2017

\begin{tabular}{|l|c|}
\hline \multicolumn{1}{|c|}{ Determinant factors } & \multicolumn{2}{c}{ Responses } & Frequency & Percentage & 217 \\
\cline { 2 - 3 } & 29.3 \\
\hline The experience gotten from many years of farming business & 117 \\
\hline The ownership of many farmlands to afford alternative practices & 113 \\
\hline Farm sizes that enable the farmers share for different management practices per season & 15.8 \\
\hline Due to the topography of the land(s) & 43 \\
\hline Knowledge obtained from participating in Government agricultural programme & 64 \\
\hline Nature of the farmlands (soil fertility status) & 8.6 \\
\hline Total responses mr & 26.6 \\
\hline
\end{tabular}

$\mathrm{mr}=$ Multiple response 


\section{Adoption of Farm Management Practices in the Sampled Settlements}

The determinants for the adoption of farm management practices among farmers in the five selected settlements have been presented in table 4. The result shows that $100.0 \%$ of the respondents cited farming experience, $96.4 \%$ of them mention nature of the farmlands were the major determinants for adopting FMPs in Zankam. In Katugal also farming experience account for the view of $70.0 \%, 40.0 \%$ recognize nature of the farmlands as the major determinants for adopting different farm management practices. The result for Madakiya shows that $100 \%$ of the respondents mention nature of the farmlands as a major determinant for adoption of farm management practices, then $85.71 \%$ of them indicate farming experience and $85.71 \%$ of them again agree that knowledge obtained in participation in Government agricultural programme contributed to the adoption of farm management practices. Furthermore, $74.2 \%$ of farmers considered ownership of many farmlands afford alternative farm management practices and $60.0 \%$ opined large farm sizes enable the farmers to divide the farmlands for different management practices per season. Land topography was not considerable for adoption of farm management practices in Madakiya because proximity to Kaduna Agricultural Development Project office at Samaru Kataf has made farmers to benefit enormously from the Government agricultural programme.

Similarly, in Mailafiya some farmers $72.9 \%$ of them identify nature of the farmlands as the major determinant then followed by farming experience with $61.4 \%$ respondents. Furthermore, $60.0 \%$ of them indicate the ownership of many farmlands affords alternative practices and large farm sizes enable them divide the farm for different management practices per season. In Kurmin sara, the common determinant was the farming experience as reveal by $77.1 \%$, then $57.4 \%$ indicated ownership of many farmlands afford alternative practices and then $55.7 \%$ cited nature of the farmlands and $45.9 \%$ opted large farm sizes enable them to divide the farm land for different management practices per season. Whereas knowledge obtained from participating in Government agricultural programme (22.9\%) and topography (9.8\%) were least considered as determinant for the adoption of farm management practice.

Table 4. Multiple Responses on the Determinant of the Adoption of Farm Practice in the Selected Settlements Source: Field Survey, 2017

\begin{tabular}{|c|c|c|c|c|c|c|}
\hline \multirow{2}{*}{$\begin{array}{c}\text { Determinants of Farm Management } \\
\text { Practices }\end{array}$} & \multicolumn{6}{|c|}{ Location } \\
\hline & Zankam & Katugal & Madakiya & Mailafiya & Kurmin Sara & Total $^{\mathrm{mr}}$ \\
\hline $\begin{array}{l}\text { The experience gotten from many years of } \\
\text { farming }\end{array}$ & $\begin{array}{c}55 \\
(100.0) \\
\end{array}$ & $\begin{array}{c}42 \\
(70.0) \\
\end{array}$ & $\begin{array}{c}30 \\
(85.71) \\
\end{array}$ & $\begin{array}{c}43 \\
(61.43) \\
\end{array}$ & $\begin{array}{c}47 \\
(77.05) \\
\end{array}$ & $\begin{array}{c}217 \\
(77.22)\end{array}$ \\
\hline $\begin{array}{l}\text { The ownership of many farmlands to afford } \\
\text { alternative practices }\end{array}$ & $\begin{array}{c}8 \\
(14.55) \\
\end{array}$ & $\begin{array}{c}6 \\
(10) \\
\end{array}$ & $\begin{array}{c}26 \\
(74.29) \\
\end{array}$ & $\begin{array}{c}42 \\
(60) \\
\end{array}$ & $\begin{array}{c}35 \\
(57.38) \\
\end{array}$ & $\begin{array}{c}117 \\
(41.64)\end{array}$ \\
\hline $\begin{array}{c}\text { Large farm sizes that enable the farmer } \\
\text { share for different management practices } \\
\text { per season }\end{array}$ & $\begin{array}{c}4 \\
(7.27)\end{array}$ & $\begin{array}{c}18 \\
(30)\end{array}$ & $\begin{array}{c}21 \\
(60)\end{array}$ & $\begin{array}{c}42 \\
(60)\end{array}$ & $\begin{array}{c}28 \\
(45.9)\end{array}$ & $\begin{array}{c}113 \\
(40.21)\end{array}$ \\
\hline Due to the topography of the land(s) & $\begin{array}{c}2 \\
(3.64) \\
\end{array}$ & $\begin{array}{c}12 \\
(20) \\
\end{array}$ & $\begin{array}{c}0 \\
(0) \\
\end{array}$ & $\begin{array}{c}13 \\
(18.57) \\
\end{array}$ & $\begin{array}{c}6 \\
(9.84) \\
\end{array}$ & $\begin{array}{c}33 \\
(11.74) \\
\end{array}$ \\
\hline $\begin{array}{l}\text { Knowledge obtained from participating in } \\
\text { Government agricultural programme }\end{array}$ & $\begin{array}{c}2 \\
(3.64) \\
\end{array}$ & $\begin{array}{c}12 \\
(20) \\
\end{array}$ & $\begin{array}{c}30 \\
(85.71) \\
\end{array}$ & $\begin{array}{c}6 \\
(8.57) \\
\end{array}$ & $\begin{array}{c}14 \\
(22.95) \\
\end{array}$ & $\begin{array}{c}64 \\
(22.78) \\
\end{array}$ \\
\hline Nature of the farmlands (soil fertility status) & $\begin{array}{c}53 \\
(96.36) \\
\end{array}$ & $\begin{array}{c}24 \\
(40) \\
\end{array}$ & $\begin{array}{c}35 \\
(100) \\
\end{array}$ & $\begin{array}{c}51 \\
(72.86) \\
\end{array}$ & $\begin{array}{c}34 \\
(55.74) \\
\end{array}$ & $\begin{array}{c}197 \\
(70.11) \\
\end{array}$ \\
\hline Total $^{\mathrm{mr}}$ & 124 & 114 & 142 & 197 & 164 & 741 \\
\hline No. & 55 & 60 & 35 & 70 & 61 & 281 \\
\hline Missing & $\mathbf{0}$ & $\mathbf{0}$ & 5 & $\mathbf{0}$ & $\mathbf{0}$ & 5 \\
\hline
\end{tabular}

Percentages and totals are based on respondents, ${ }^{\mathrm{mr}}=$ Multiple response

Thus, first of all farmers about $77.24 \%$ considered the farming experience acquired in many years of farming, then some $70.11 \%$ recognized nature of the farmlands before adopting any farm management practice. The other factors considered were the ownership of many farmlands afford alternative practices as well as large farm sizes which enabled them divide the farm land for different management practices per season (41.\%). However, knowledge obtained from participating in Government agricultural programme $(22.78 \%)$ was less concerned and virtually all 
the farmers did not consider it together with topography of the land (11.74\%) as a determinant due to the relatively flat to gentle terrain of the regions.

\section{CONCLUSION AND RECOMMENDATIONS}

The study establishes different farm management practices adopted by farmers under indigenous and modern techniques of farming. Farming experience and nature of soil fertility status of the farmlands were the major determinants for the adoption of the common farm management practices. While age, household size, land tenure, farm size and distance of farm plot from homestead were influenced significantly for farmers' choice of land management practices. The study recommends the revitalization of abandoned irrigation infrastructures in Kagoro and Madakiya to take the full potential of the availability of fadamas, including the marshy areas and streams with alluvial banks deposits. This would encourage farmers to participate fully in irrigation agriculture. It is necessary to help the farmers in order to improve the management of their agricultural farm lands in the study area at two levels. First, those practices that are common in each settlement should be targeted for improvement. Second, farm land management practices that are not currently being used by farmers in each settlement but have the potential to improve crop production should be identified and promoted in the respective settlements.

\section{Acknowledgement}

The corresponding author acknowledges the various contributions made by the co-authors to enrich and update this paper.

\section{REFERENCES}

Abaje, I. B., Ati, O. F., \& Ishaya, S. (2009). Nature of Potable Water Supply and Demand in Jema'a Local Government Area of Kaduna State, Nigeria. Resource Journal of Environmental Earth Science, 1(1), 16-21.

Abaje, I. B., Ishaya, S., \& Usman, S. U. (2010). An Analysis of Rainfall Trends in Kafanchan, Kaduna State, Nigeria. Research Journal of Environmental and Earth Sciences, 2(2), 89-96.

Abaje, I. B., Sawa, B. A., Iguisi, E. O., \& Ibrahim, A. A. (2016). Assessment of Rural Communities' Adaptive Capacity to Climate Change in Kaduna State, Nigeria. Journal of Environment and Earth Science, 5(20), 14-23.

Akpoko, J .G. (2004). Factors Affecting Adoption of Recommended Soil Management Practices for Sustainable Agriculture in Kaduna State, Nigeria. Savanna, 19(2), 21-32.

Aregheore, E. M. (2005). Country pasture/forage resource profiles: Nigeria. Food and Agriculture Organisation of the United Nations, Italy.

Babalola, D.A. \& Olayemi, J.K. (2013). Determinants of Farmers' Preference for Sustainable Land Management Practices for Maize and Cassava Production in Ogun State, Nigeria. Invited Paper Presented at the $4^{\text {th }}$ International Conference of the African Association of Agricultural Economists, Hammamet, Tunisia.

Bewket, W. (2007). Soil and Water Conservation Intervention with Conventional Technologies in North-Western Highlands of Ethiopia: Acceptance and Adoption by Farmers. Land Use Policy, 24, 404-416.

Cohen, L. Manion, L. \& Morrison K. (2011). Research Methods in Education. ( $7^{\text {th }}$ Edition). Great Britain. Ashford Colour Press Ltd.

Ersado, L., Amacher, G., \& Alwang, J. (2004). Productivity and land enhancing technologies in northern Ethiopia: Health, public investments, and sequential adoption. American Journal of Agricultural Economics, 86(2), 321-331.

Geissen, V., Sánchez-Hernández, R., Kampichler, C., Ramos-Reyes, R., Sepulveda-Lozada, A., Ochoa-Goana, S., ... \& Hernández-Daumas, S. (2009). Effects of land-use change on some properties of tropical soils - an example from Southeast Mexico. Geoderma, 151(3-4), 87-97.

Global Environmental Facility (2016). Sustainable Land Management and its Relationship to Global Environmental Benefits and Food Security: A Synthesis report for the GEF.

Holden, S., \& Yohannes, H. (2002). Land redistribution, tenure insecurity, and intensity of production: A study of farm households in Southern Ethiopia. Land Economics, 78(4), 573-590.

Junge, B., Abaidoo, R., Chickoye, D., Stahr, K. \& Lal, R. (2008). Research Report on Soil Conservation in Nigeria: Past and Present on -Station and on-Farm Initiatives. Soil and Water Conservation Society, Ankeny, Iowa, USA.

Kong, T. M. (2016). What Influences Farmers' Land Management Practices to Combat Land Degradation? Landscapes for People, Food and Nature.

Lal, R. (2015). Restoring soil quality to mitigate soil degradation. Sustainability, 7(5), 5875-5895.

Miheretu, B. A., \& Yimer, A. A. (2017). Determinants of farmers' adoption of land management practices in Gelana subwatershed of Northern highlands of Ethiopia. Ecological Processes, 6(1), 19-29. 
Ministry of Land and Survey (2014). Map of the Northern Guinea Savanna Agro-ecological Zones of Kaduna State.

Muhammad, L. A., Kemi, F. O., Olabisi, F. A., \& Dayo, A. (2014). Assessment of Land Management Practices in Food Crops Production among Small Scale Farmers in Kwara State, Nigeria. International Journal of Agricultural Management and Development, 4(2), 105-116.

Oriola, E. O. (2009). Breaking the vicious cycle in irrigation farming system for sustainable food security in Nigeria. African Research Review, 3(1), 234-245.

Raufu, M. O., \& Adetunji, M. O. (2012). Determinant of land management practices among crop farmers in South-Western Nigeria. Global Journal of Science Frontier Research Agriculture \& Biology, 12(1), 8-14.

Terr Africa Partnership. (2006). Regional Sustainable land Management [Brochure]. Washington DC, USA.

Submitted:

December 12, 2019
Revised:

April 10, 2020
Accepted and published online

June 16, 2020 